FAST-FORWARD FAMILY 
This page intentionally left blank 


\section{Fast-Forward Family}

Home, Work, and Relationships

in Middle-Class America

Edited by ELINOR OCHS

and TAMAR KREMER-SADLIK

甲

UNIVERSITY OF CALIFORNIA PRESS

Berkeley Los Angeles London 
University of California Press, one of the most distinguished university presses in the United States, enriches lives around the world by advancing scholarship in the humanities, social sciences, and natural sciences. Its activities are supported by the UC Press Foundation and by philanthropic contributions from individuals and institutions. For more information, visit www.ucpress.edu.

University of California Press

Berkeley and Los Angeles, California

University of California Press, Ltd.

London, England

(C) 2013 by The Regents of the University of California

Illustrations and photos appear by permission of CELF.

Library of Congress Cataloging-in-Publication Data

Fast-forward family : home, work, and relationships in middle-class America / edited by Elinor Ochs and Tamar Kremer-Sadlik.

p. $\mathrm{cm}$.

Includes bibliographical references and index.

ISBN 978-0-520-27397-9 (cloth : alk. paper)

ISBN 978-o-520-27398-6 (pbk. : alk. paper)

r. Middle-class families-United States. 2. Work and family-

United States. I. Ochs, Elinor. II. Kremer-Sadlik, Tamar.

HQ536.F388 2013

306.850973-dc23

2OI2O273OI

Manufactured in the United States of America

$\begin{array}{llllllllll}22 & 2 \mathrm{I} & 2 \mathrm{O} & \text { I9 } & \text { I8 } & \text { I7 } & \text { I6 } & \text { I5 } & \text { I4 } & \text { I3 } \\ \text { IO } & 9 & 8 & 7 & 6 & 5 & 4 & 3 & 2 & \text { I }\end{array}$

In keeping with a commitment to support environmentally responsible and sustainable printing practices, UC Press has printed this book on Rolland EnviroIoo, a I0o\% post-consumer fiber paper that is FSC certified, deinked, processed chlorine-free, and manufactured with renewable biogas energy. It is acid-free and EcoLogo certified. 
To the thirty-two families that inspired this study 
This page intentionally left blank 